\title{
Angiotensin-I converting enzyme insertion/deletion polymorphism and its association with diabetic nephropathy: a meta-analysis of studies reported between 1994 and 2004 and comprising 14,727 subjects
}

Received: 22 July 2004 / Accepted: 19 December 2004 / Published online: 14 April 2005

(C) Springer-Verlag 2005

\begin{abstract}
Aims/hypothesis: The ACE insertion/deletion polymorphism has been examined for association with diabetic nephropathy over the past decade with conflicting results. To clarify this situation, we conducted a comprehensive meta-analysis encompassing all relevant studies that were published between 1994 and 2004 and investigated this potential genetic association. Methods: A total of 14,727 subjects from 47 studies was included in this meta-analysis. Cases $(n=8,663)$ were type 1 or 2 diabetic subjects with incipient (microalbuminuria) or advanced diabetic nephropathy (proteinuria, chronic renal failure, end-stage renal disease). Control subjects $(n=6,064)$ were predominantly normoalbuminuric. Results: No obvious publication bias was detected. Using a minimal-case definition based on incipient diabetic nephropathy, subjects with the II genotype had a $22 \%$ lower risk of diabetic nephropathy than carriers of the $\mathrm{D}$ allele (pooled odds ratio $[\mathrm{OR}]=0.78,95 \% \mathrm{CI}=0.69-0.88)$. While there was a reduced risk of diabetic nephropathy associated with the II genotype among Caucasians with either type 1 or type 2 diabetes, the association was most marked among type 2 diabetic Asians (Chinese, Japanese, Koreans) $(\mathrm{OR}=0.65$, $95 \% \mathrm{CI}=0.51-0.83)$. This $\mathrm{OR}$ is significantly different from the OR of $0.90(95 \% \mathrm{CI}=0.78-1.04)$ that was obtained for type 2 diabetic Caucasians $(p=0.019)$. Using a stricter case definition based on advanced diabetic nephropathy, a comparable risk reduction of $24-32 \%$ was observed among the three subgroups, although statistical significance was reached only among Asians. Conclusions/
\end{abstract}

\footnotetext{
D. P. K. Ng $(\bowtie) \cdot$ B. C. Tai · D. Koh · K. S. Chia 16, Medical Drive,

Singapore, 117597, Singapore

e-mail: cofnpkd@nus.edu.sg

Tel.: +65-6874-4967

Fax: +65-6779-1489

D. P. K. Ng • B. C. Tai · K. W. Tan · K. S. Chia

Centre for Molecular Epidemiology,

National University of Singapore,

Singapore, Singapore
}

Department of Community, Occupational and Family Medicine,

Faculty of Medicine (MD3), National University of Singapore, interpretation: The results of our meta-analysis support a genetic association of the $A C E$ Ins/Del polymorphism with diabetic nephropathy. These findings may have implications for the management of diabetic nephropathy using ACE inhibitors especially among type 2 diabetic Asians.

Keywords ACE polymorphism - Diabetes mellitus · Ethnic variation $\cdot$ Publication bias $\cdot$ Random effects model

Abbreviations OR: odds ratio

\section{Introduction}

Diabetic nephropathy is the most serious complication of diabetes mellitus and affects approximately a third of diabetic patients. Importantly, it is the leading cause of endstage renal disease requiring dialysis or transplantation in developed countries [1] as well as in rapidly developing countries in Asia [2]. Besides good glycaemic control, measures such as the attenuation of the renin-angiotensin system using ACE inhibitors are important in the clinical management of this complication [3]. However, the efficacy of ACE inhibitors in treating diabetic nephropathy can be influenced by genetic variation at the $A C E$ gene locus $[4,5]$. Specifically, a polymorphism termed Ins/Del, which results from the insertion/deletion of a $287 \mathrm{bp}$ Alu sequence in intron 16, accounts for half the variance of serum enzyme levels with individuals homozygous for the insertion allele (II genotype) having significantly lower levels than carriers of the deletion allele (ID and DD genotypes) [6].

Studies of familial clustering have consistently demonstrated that genetic susceptibility plays an important role in diabetic nephropathy [7]. Regarding $A C E$, investigators have sought to determine if the Ins/Del polymorphism acts as a genetic risk factor for diabetic nephropathy, beginning with the initial study by Marre et al in 1994, who reported a protective effect of the II genotype on the development of this complication [8]. However, meta-analyses pub- 
lished in 1998 did not support this conclusion among Caucasians with either type 1 or type 2 diabetes, although the II genotype appeared protective among type 2 diabetic Asians of Japanese and Korean origin $[9,10]$. While genetic susceptibility linked to the $A C E$ locus may be population-specific, an important caveat is that these earlier reviews were conducted on just around 20 studies and comprised about 5,000 subjects each. This limited data did not allow firm conclusions from such detailed subgroup analyses $[9,10]$. A third meta-analysis did not include the relevant subgroup analyses [11].

Since 1998, there has been a considerable surge in the number of reports on the association of the $A C E$ Ins/Del polymorphism with diabetic nephropathy. Indeed, our present literature search indicated that the number of such publications has doubled at least since the previous metaanalyses. In light of this significant development, we conducted a new meta-analysis based on 47 studies published during the decade starting from 1994 and which comprises 14,727 diabetic subjects.

\section{Subjects, materials and methods}

Identification of studies We identified studies (case-control, cross-sectional or cohort study designs) that examined the association of the $A C E$ Ins/Del polymorphism with diabetic nephropathy and were published from 1994 to March 2004, beginning with the first report by Marre et al [8]. Studies were identified by searching the PubMed database (http://www.ncbi.nlm.nih.gov/PubMed/) using the keywords 'angiotensin converting enzyme', 'diabetes', 'diabetic nephropathy', 'end-stage renal disease' and 'polymorphism', with keywords used singly and in various combinations. All studies included in previous meta-analyses were also considered [9-11]. The reference lists from all identified studies were also scrutinised to search for additional reports. Studies were considered, if they provided sufficient information to allow a comparison of the $A C E$ Ins/Del genotype distribution between cases and control subjects. Cases were type 1 or 2 diabetic subjects with incipient (microalbuminuria) or advanced diabetic nephropathy (proteinuria/macroalbuminuria, chronic renal failure, end-stage renal disease), while control subjects were defined predominantly on the basis of normoalbuminuria (Table 1).

Selection of studies for inclusion Fifty-eight studies arising from 57 individual publications were identified for possible inclusion in this meta-analysis [8, 12-67]. Of these, nine studies appeared to overlap with more recent publications and were excluded to avoid partial or complete duplication of data $[8,18,35,42,48,53,57,60,67]$. A study by Gutierrez et al. [28] was excluded since it reported only allele, but not genotype distributions. A small study $(n=30)$ was excluded as the published data did not allow an estimation of the study-specific OR or its contribution to the pooled OR, since there were empty cells in the reported genotype distributions [62]. The remaining 47 studies ful- filled the criteria for inclusion in this review. Together, these studies comprised 8,663 cases and 6,064 control subjects, yielding a total of 14,727 subjects.

Data extraction The following information was extracted from the selected studies: names of first and corresponding authors, year of publication, journal citation, country in which the study was conducted, race of study population, study design, genotyping method, type of diabetes, case/control definitions and genotype distribution of the Ins/Del.

Statistical analyses Funnel plots of the effect estimate based on $\log$-odds ratio were plotted against the reciprocal of its standard error to evaluate the possibility of publication bias [68]. The chi square test for goodness-of-fit was used to determine if there was significant deviation from Hardy-Weinberg equilibrium among the control subjects in the individual studies. The magnitude of the genetic association between the $A C E$ Ins/Del polymorphism and diabetic nephropathy was obtained by calculating the odds ratio (OR) and its associated $95 \%$ CI. A random effects model was employed to summarise the data. This model assumes that the 47 studies selected for inclusion in the review are a random sample from the larger population of such studies, with each study having its own underlying effect size. Under this model, it is assumed that there is a mean population effect size, about which the study-specific ORs vary. As the random effects model properly takes into account the inter-study heterogeneity such as differences in study design (case-control, cross-sectional and cohort studies) and case definitions for diabetic nephropathy, it provides a more conservative evaluation of the significance of the association than one based on fixed effects [69]. Data from the small number of cohort studies were included in the meta-analyses (Table 1); cases and control subjects were defined according to patient phenotypes after the duration of follow-up specified for each study. The stratification of studies by type of diabetes was subsequently considered. Subgroup analysis of data for type 1 diabetic subjects was restricted to Caucasians since these represented the majority $(75 \%)$ of such studies. In the case of type 2 diabetic subjects, we analysed the data for Caucasians and Asians separately. The Asian subgroup consisted of Chinese, Japanese and Korean subjects from 16 studies. The risk of diabetic nephropathy attributable to carriage of the D allele was calculated using the formula $\hat{\lambda}=\frac{a d-b c}{d(a+b)}$ where $a$ and $c$ are the number of cases and control subjects who are carriers of the D allele, while $b$ and $d$ are cases and control subjects homozygous for the I allele [70].

\section{Results}

Studies selected for inclusion Forty-seven studies, comprising 8,663 cases and 6,064 controls, fulfilled the criteria for inclusion in this review (Table 1). Twenty studies (16 
1010

Table 1 Summary of the 47 studies included in the meta-analysis

\begin{tabular}{|c|c|c|c|c|c|c|c|c|c|c|c|c|c|}
\hline \multirow[t]{2}{*}{ First author } & \multirow[t]{2}{*}{ Ref. } & \multirow[t]{2}{*}{ Year } & \multirow[t]{2}{*}{ Race } & \multirow[t]{2}{*}{ Design } & \multirow[t]{2}{*}{ Diabetes } & \multirow{2}{*}{$\begin{array}{l}\text { Case } \\
\text { definition } \\
\text { (renal status) }\end{array}$} & \multirow{2}{*}{$\begin{array}{l}\text { Control } \\
\text { definition } \\
\text { (renal status) }\end{array}$} & \multicolumn{3}{|c|}{$\begin{array}{l}\text { Case } \\
\text { genotypes }(n)\end{array}$} & \multicolumn{3}{|c|}{$\begin{array}{l}\text { Control } \\
\text { genotypes }(n)\end{array}$} \\
\hline & & & & & & & & DD & ID & II & DD & ID & II \\
\hline Doria & {$[12]$} & 1994 & Caucasian & $\mathrm{CC}$ & Type 1 & Micro, Prot, ESRD & Normo & 24 & 35 & 15 & 16 & 41 & 2 \\
\hline Powrie & {$[13]$} & 1994 & Caucasian & $\mathrm{CH}$ & Type 1 & Micro & $\begin{array}{l}\text { Normo after } 10 \\
\text { years follow-up }\end{array}$ & 7 & 8 & 4 & 24 & 37 & 2 \\
\hline Dudley & [14] & 1995 & Caucasian & $\mathrm{CC}$ & Type 2 & $\begin{array}{l}\text { Top tertile of } \\
\text { albuminuria }\end{array}$ & $\begin{array}{l}\text { Excluding top } \\
\text { tertile }\end{array}$ & 47 & 85 & 31 & 70 & 148 & 49 \\
\hline Fujisawa & {$[15]$} & 1995 & $\begin{array}{l}\text { Asian } \\
\text { Japanese }\end{array}$ & $\mathrm{CC}$ & Type 2 & Prot, HD & $\begin{array}{l}\text { No Prot with } \\
\mathrm{DM} \geq 10 \text { years }\end{array}$ & 7 & 23 & 24 & 6 & 12 & 17 \\
\hline Mizuiri & [16] & 1995 & $\begin{array}{l}\text { Asian } \\
\text { Japanese }\end{array}$ & $\mathrm{CS}$ & Type 2 & Micro, Prot, CRF & $\begin{array}{l}\text { Normo, with } \\
D M \geq 10 \text { years }\end{array}$ & 19 & 50 & 11 & 9 & 11 & 11 \\
\hline Panagiotopoulos & {$[17]$} & 1995 & Caucasian & $\mathrm{CS}$ & Type 2 & Micro, Prot & Normo & 15 & 25 & 10 & 42 & 44 & 29 \\
\hline Schmidt & {$[18]$} & 1995 & Caucasian & $\mathrm{CC}$ & Type 1 & Micro at least & Normo & 52 & 38 & 24 & 55 & 55 & 2 \\
\hline Tarnow & [19] & 1995 & Caucasian & $\mathrm{CC}$ & Type 1 & Prot & Normo & 63 & 95 & 40 & 67 & 77 & 4 \\
\hline Rabensteiner & {$[20]$} & 1995 & Caucasian & $\mathrm{CC}$ & Type 1 & Micro, Prot & Normo & 16 & 39 & 9 & 8 & 33 & 1 \\
\hline Chowdhury & {$[21]$} & 1996 & Caucasian & $\mathrm{CC}$ & Type 1 & Prot & $\begin{array}{l}\text { No Prot with } \\
\text { DM }>15 \text { years }\end{array}$ & 78 & 124 & 40 & 55 & 79 & 32 \\
\hline Doi & {$[22]$} & 1996 & $\begin{array}{l}\text { Asian } \\
\text { Japanese }\end{array}$ & $\mathrm{CC}$ & Type 2 & $\begin{array}{l}\text { Micro, Prot, } \\
\text { CRF, HD }\end{array}$ & $\begin{array}{l}\text { Normo with } \\
\mathrm{DM}<10 \text { years }\end{array}$ & 29 & 85 & 50 & 12 & 56 & 56 \\
\hline Nakajima & [23] & 1996 & $\begin{array}{l}\text { Asian } \\
\text { Japanese }\end{array}$ & CS & Type 2 & Micro, Prot & Normo & 14 & 50 & 37 & 4 & 19 & 18 \\
\hline $\mathrm{Oh}$ & [24] & 1996 & $\begin{array}{l}\text { Asian } \\
\text { Korean }\end{array}$ & $\mathrm{CS}$ & Type 1 & $\begin{array}{l}\text { Micro, Prot, } \\
\text { ESRD }\end{array}$ & Normo & 10 & 9 & 12 & 7 & 10 & 11 \\
\hline Ohno & {$[25]$} & 1996 & $\begin{array}{l}\text { Asian } \\
\text { Japanese }\end{array}$ & CS & Type 2 & Micro, Prot, & Normo & 15 & 38 & 26 & 5 & 15 & 33 \\
\hline Yoshida & [26] & 1996 & $\begin{array}{l}\text { Asian } \\
\text { Japanese }\end{array}$ & $\mathrm{CS}$ & Type 2 & CRF, ESRD & $\begin{array}{l}\text { Stable renal } \\
\text { function }\end{array}$ & 19 & 28 & 25 & 7 & 46 & 43 \\
\hline Barnas & {$[27]$} & 1997 & Caucasian & $\mathrm{CC}$ & Type 1 & $\begin{array}{l}\text { Micro, Prot, } \\
\text { CRF, HD }\end{array}$ & $\begin{array}{l}\text { Normo with } \\
\mathrm{DM}>20 \text { years }\end{array}$ & 14 & 27 & 9 & 4 & 21 & 15 \\
\hline Hibberd & [29] & 1997 & Caucasian & $\mathrm{CC}$ & Type 1 & Prot & $\begin{array}{l}\text { Normo with } \\
D M \geq 20 \text { years }\end{array}$ & 21 & 42 & 9 & 36 & 43 & \\
\hline Jeffers & {$[30]$} & 1997 & Caucasians & CS & Type 2 & Prot & No Prot & 23 & 20 & 7 & 139 & 218 & 102 \\
\hline Marre & {$[31]$} & 1997 & Caucasian & $\mathrm{CS}$ & Type 1 & $\begin{array}{l}\text { Micro, Prot, } \\
\text { CRF, ESRD }\end{array}$ & Normo & 119 & 168 & 50 & 48 & 69 & 40 \\
\hline Ringel & {$[33]$} & 1997 & Caucasian & $\mathrm{CS}$ & Type 1 & Micro, ESRD & Normo & 35 & 68 & 31 & 57 & 130 & 35 \\
\hline Ringel & {$[33]$} & 1997 & Caucasian & $\mathrm{CS}$ & Type 2 & Micro, ESRD & Normo & 44 & 84 & 33 & 35 & 69 & 36 \\
\hline Demurov & [34] & 1997 & Caucasian & $\mathrm{CC}$ & Type 1 & Prot & Normo & 24 & 29 & 3 & 24 & 32 & 20 \\
\hline Schmidt & {$[35]$} & 1997 & Caucasian & $\mathrm{CC}$ & Type 2 & $\begin{array}{l}\text { Micro at least, } \\
\text { ESRD }\end{array}$ & $\begin{array}{l}\text { Normo with } \\
D M \geq 10 \text { years }\end{array}$ & 121 & 129 & 61 & 131 & 154 & 62 \\
\hline Pfohl & {$[32]$} & 1998 & Caucasian & CS & Type 1 & Micro, Prot, HD & Normo & 17 & 15 & 8 & 15 & 18 & \\
\hline Freire & {$[37]$} & 1998 & Jews & $\mathrm{CS}$ & Type 1 & Micro, Prot & $\begin{array}{l}\text { Normo with } \\
D M \geq 10 \text { years }\end{array}$ & 33 & 32 & 12 & 34 & 45 & 10 \\
\hline Grzeszczak & {$[38]$} & 1998 & Caucasian & $\mathrm{CC}$ & Type 2 & Micro, Prot, CRF & $\begin{array}{l}\text { Normo with } \\
D M>10 \text { years }\end{array}$ & 129 & 230 & 103 & 73 & 118 & 63 \\
\hline Hanyu & [39] & 1998 & $\begin{array}{l}\text { Asian } \\
\text { Japanese }\end{array}$ & $\mathrm{CS}$ & Type 2 & Micro at least & Normo & 4 & 13 & 7 & 2 & 5 & 14 \\
\hline Huang & {$[40]$} & 1998 & Caucasian & $\mathrm{CH}$ & Type 2 & Micro, Prot & $\begin{array}{l}\text { Normo after } 9 \\
\text { years follow-up }\end{array}$ & 11 & 16 & 2 & 20 & 25 & \\
\hline $\mathrm{Wu}$ & {$[41]$} & 1998 & $\begin{array}{l}\text { Asian } \\
\text { Chinese }\end{array}$ & $\mathrm{CC}$ & Type 2 & $\begin{array}{l}\text { Diabetic nephropathy } \\
\text { not explicitly } \\
\text { defined }\end{array}$ & $\begin{array}{l}\text { No diabetic } \\
\text { nephropathy }\end{array}$ & 12 & 18 & 21 & 1 & 11 & 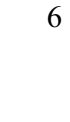 \\
\hline Bouhanick & {$[43]$} & 1999 & Caucasian & $\mathrm{CS}$ & Type 1 & Micro & Normo & 4 & 5 & 4 & 19 & 34 & 10 \\
\hline De Cosmo & {$[44]$} & 1999 & Caucasian & $\mathrm{CC}$ & Type 1 & Micro, Macro & $\begin{array}{l}\text { Normo with } \\
\text { DM }>15 \text { years }\end{array}$ & 73 & 79 & 23 & 65 & 53 & 18 \\
\hline
\end{tabular}


Table 1 (continued)

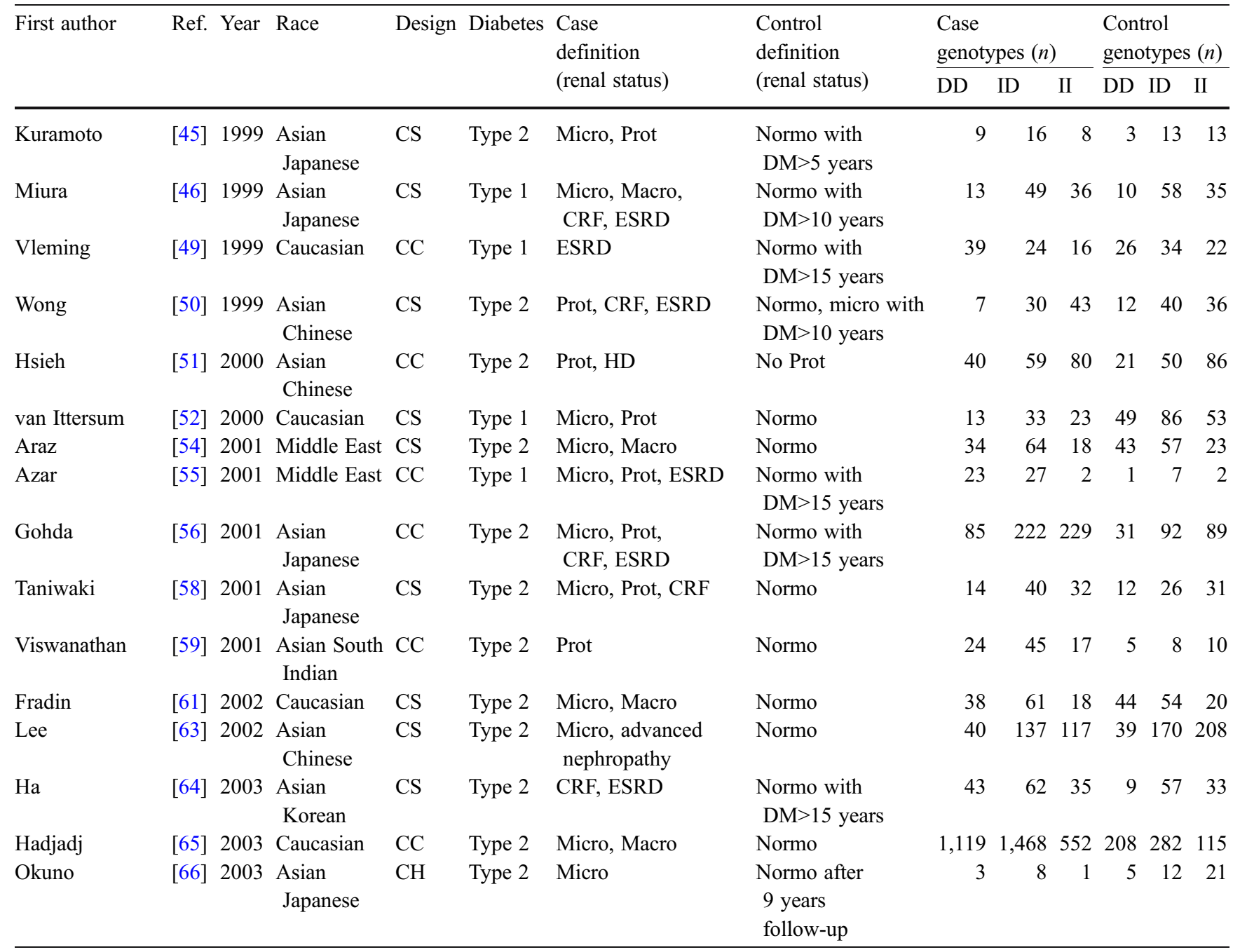

CC case-control, $C S$ cross-sectional, $C H$ cohort, Normo normoalbuminuria, Micro microalbuminuria, Prot proteinuria, Macro macroalbuminuria, $C R F$ chronic renal failure, $E S R D$ end-stage renal disease, $H D$ haemodialysis, $D M$ diabetes mellitus

Caucasian, 4 non-Caucasian) involved type 1 diabetic subjects, while the remaining 27 studies were conducted on patients with type 2 diabetes (9 Caucasian, 16 Asian and 2 others). The 16 studies on type 1 diabetic Caucasians contributed 1,736 cases and 1,801 control subjects. Among the type 2 diabetic studies, studies involving Caucasians contributed 4,482 cases and 2,359 control subjects, while the Asian studies included 1,985 cases and 1,528 control subjects.

Publication bias and Hardy-Weinberg equilibrium The potential presence of publication bias was evaluated using a funnel plot of the estimate of log-odds ratio for the genotype II versus DD+ ID against the reciprocal of its standard error (Fig. 1). There was considerable scatter around the pooled log-odds ratio estimate when the reciprocal of the standard error was small (i.e. corresponded to small studies); this scattering converged as the reciprocal of the standard error increased (i.e. corresponded to larger studies). The resulting symmetrical funnel shape was consistent with an absence of publication bias since small studies with negative results were as likely to be published (Fig. 1a). No obvious funnel asymmetry was observed when this plot was repeated for studies comprising Caucasians with type 1 or type 2 diabetes and for studies of Asians with type 2 diabetes alone (Fig. 1b-d). Of the 47 studies, only two had control groups whose genotype distributions did not conform to that expected under HardyWeinberg equilibrium $[19,51]$. For completeness of this review, these studies were retained for the data analysis. Exclusion of these studies did not materially alter the conclusions of this review (data not shown).

Association of Ins/Del with diabetic nephropathy - estimation of pooled OR To evaluate the magnitude of the association between $A C E$ Ins/Del and diabetic nephropathy, we 
a

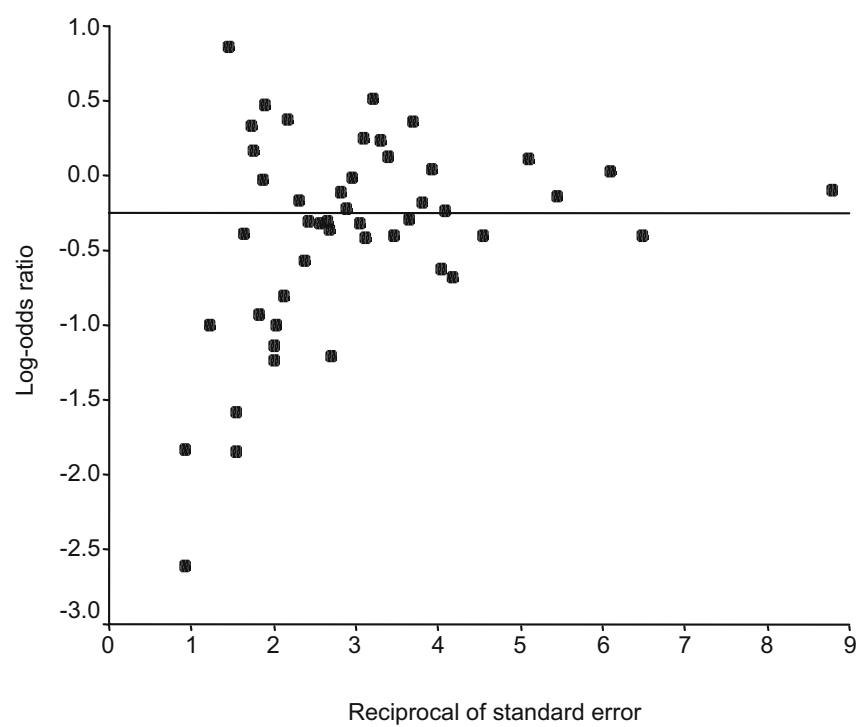

C

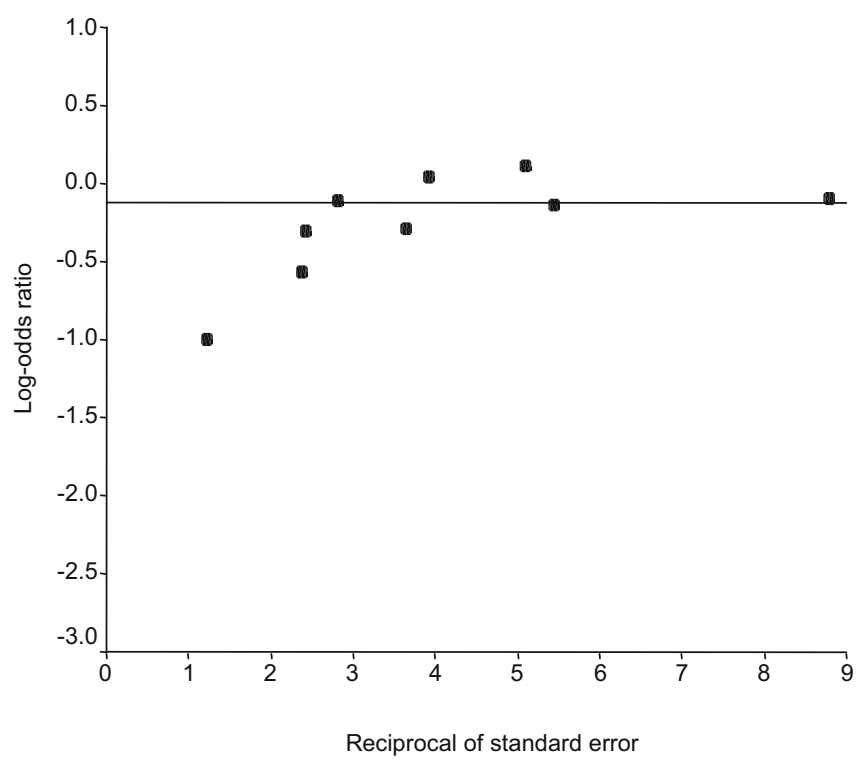

Fig. 1 Evaluation of publication bias using funnel plots. Plots are shown for all studies (a), and subgroups involving type 1 diabetic Caucasians (b), as well as Caucasians and Asians with type 2 dia-

generated study-specific and pooled OR estimates for the comparison of the II genotype versus ID and DD genotypes separately. The ORs for II vs DD and II vs ID were 0.70 (95\% CI $0.60-0.83)$ and 0.82 (95\% CI $0.72-0.93)$ respectively. Thus, the risk of diabetic nephropathy associated with either DD or ID genotypes was of similar magnitude, and was consistent with II being the protective genotype. Based on all 47 studies, subjects with the II genotype had a $22 \%$ lower risk of diabetic nephropathy than carriers of the $\mathrm{D}$ allele (pooled $\mathrm{OR}=0.78,95 \% \mathrm{CI}=0.69-0.88$ ) (Fig. 2).

We next refined our analysis by focussing on subgroups of studies comprising solely type 1 diabetic Caucasians, type 2 diabetic Caucasians and type 2 diabetic Asians. b

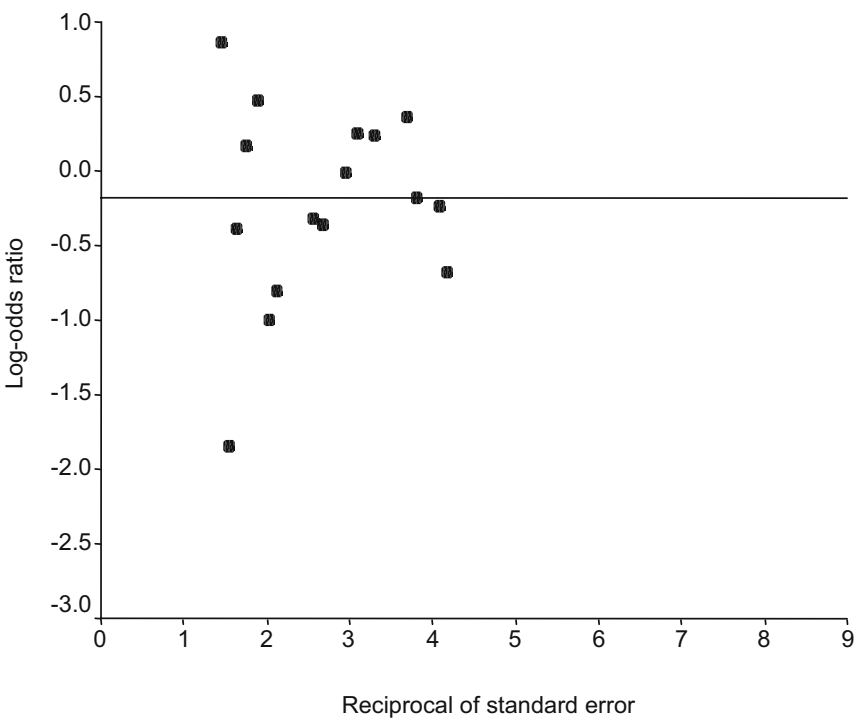

d

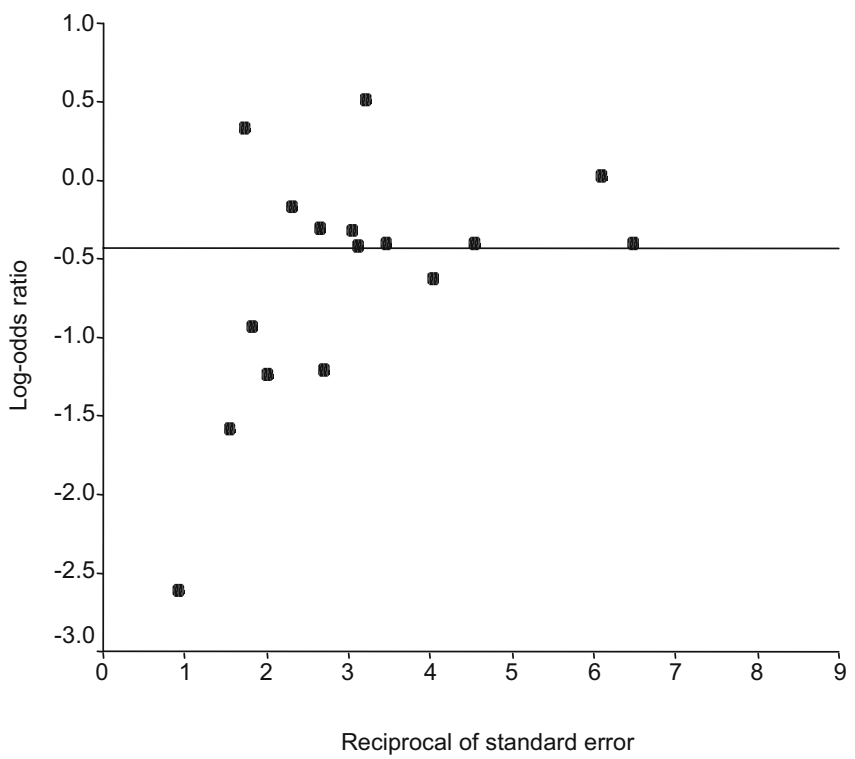

betes $(\mathbf{c}, \mathbf{d})$. No significant funnel asymmetry was observed which could indicate publication bias

While all three subgroup analyses showed that the II genotype is associated with a reduced risk of diabetic nephropathy, the association was most marked among Asians with type 2 diabetes. Specifically, Asians who were II homozygotes had a $35 \%$ reduction in risk of diabetic nephropathy compared to those carrying the $\mathrm{D}$ allele $(\mathrm{OR}=$ $0.65,95 \%$ CI $=0.51-0.83$ ). This $35 \%$ reduction in risk associated with the II genotype was significantly greater than the $10 \%$ observed among type 2 diabetic Caucasians $(\mathrm{OR}=0.90,95 \% \mathrm{CI}=0.78-1.04)(p=0.019)$, indicating that these subgroups were heterogeneous with regard to the association of the $A C E$ Ins/Del with diabetic nephropathy. A small reduction in risk of diabetic nephropathy asso- 


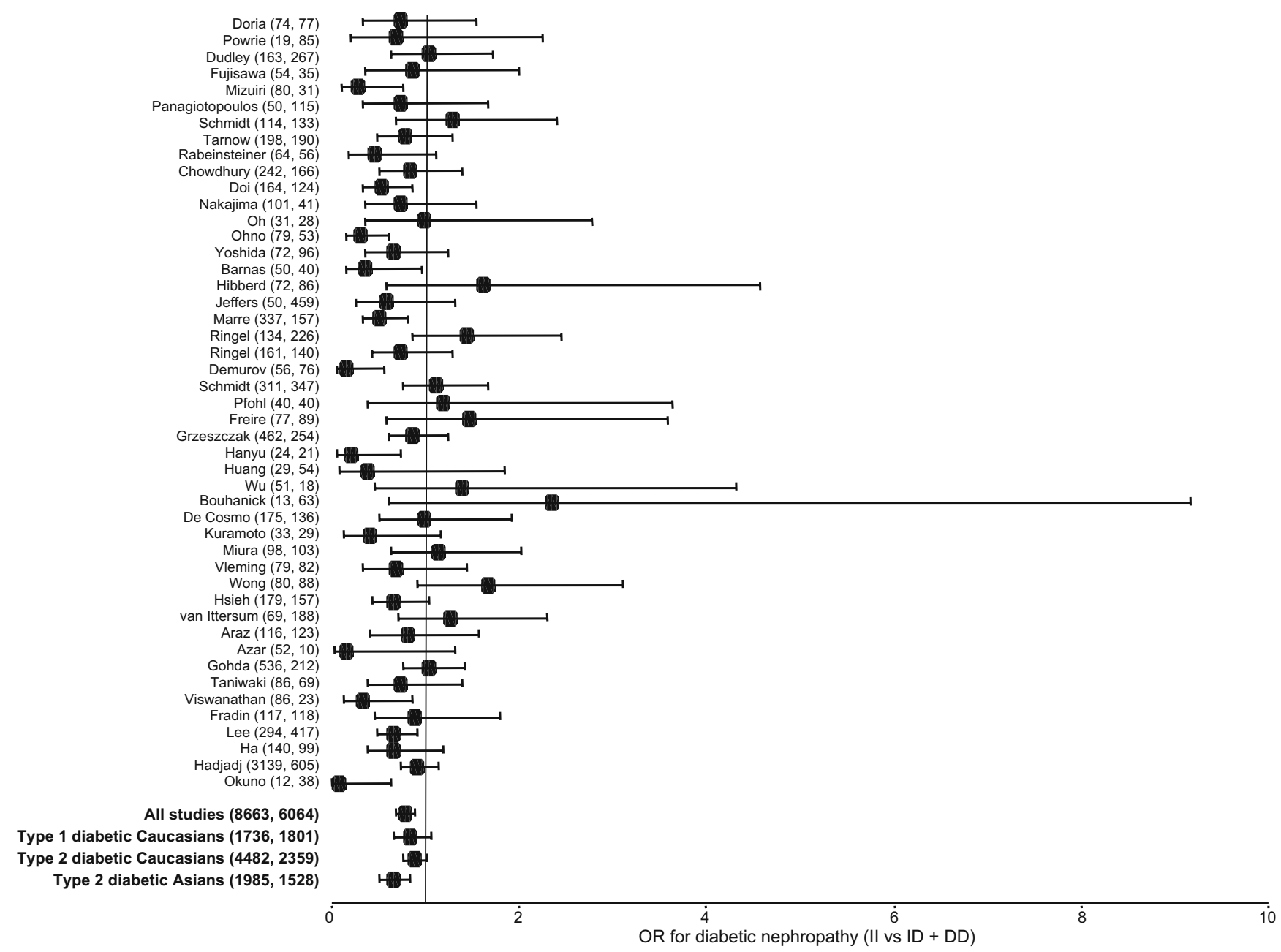

Fig. 2 Odds ratios (ORs) and the associated 95\% CI comparing ACE II versus ID and DD genotypes combined. The graph shows individual and pooled estimates for all studies, and studies on type 1 diabetic Caucasians, as well as Caucasians and Asians with type 2

ciated with the II genotype also failed to reach statistical significance among the subgroup comprising 3,537 Caucasian patients with type 1 diabetes $(\mathrm{OR}=0.83,95 \% \mathrm{CI}=$ $0.65-1.07)$. Subgroup analysis was not performed for Asians with type 1 diabetes, since only two such studies were included in this review. The risk attributable to car riage of the $\mathrm{D}$ allele among type 2 diabetic Asians was modest at 20\% (see Subjects, materials and methods).

A minimum diabetes duration, after which control subjects continued to be normoalbuminuric, was specified in several of the 47 studies (Table 1) and use of this subset of control subjects may reduce case misclassification. We therefore analysed the studies that employed such 'longduration control subjects'. The OR for studies on type 1 diabetic Caucasians $[13,27,29,44,49]$ was $0.78(95 \% \mathrm{CI}$ $0.51-1.21)$. For studies on type 2 diabetic Caucasians [35, $38,40]$ and Asians $[16,45,50,56,64,66]$, the OR estimates were 0.95 (95\% CI $0.71-1.27)$ and 0.65 (95\% CI $0.37-1.15)$ respectively. These results were very similar to when all controls were considered, albeit with wider con- diabetes. Cases were defined on the minimal criterion of microalbuminuria. The number of cases and control subjects for each study are in brackets

fidence intervals as expected. Thus confining our analyses to studies with long-duration control subjects did not materially alter our findings.

The case definition employed in the published studies varied, ranging from incipient (indicated by microalbuminuria) to advanced diabetic nephropathy (proteinuria, chronic renal failure, end-stage renal disease). Thus, we repeated the meta-analyses based on 12 reports that had defined cases solely on the presence of advanced diabetic nephropathy $[15,19,21,26,29,30,34,49-51,59,64]$. This was supplemented with data from 12 additional studies, which had separately furnished the genotype distributions of such advanced cases in their reports [22, 23, 25, 31, 35, $38,46,52,54,56,58,61]$ (Table 1). The overall pooled OR based on 2,529 advanced cases and 3,346 control subjects was $0.74(95 \% \mathrm{CI}=0.62-0.88)$. The reduction in risk associated with the II genotype was highly comparable among type 1 diabetic Caucasians $(\mathrm{OR}=0.72,95 \% \mathrm{CI}=0.49-1.05)$, type 2 diabetic Caucasians $(\mathrm{OR}=0.68,95 \% \mathrm{CI}=0.39-1.16)$ and Asians with type 2 diabetes $(\mathrm{OR}=0.76,95 \% \mathrm{CI}=0.59$ 
0.96), with the association in the latter subgroup being statistically significant $(p=0.0229)$.

\section{Discussion}

The discovery of susceptibility genes for diabetic nephropathy could lead to novel avenues for the prevention and treatment of this debilitating complication [71]. Regarding $\mathrm{ACE}$, an understanding of its genetic basis may facilitate the identification of specific patient subgroups that might benefit from targeted treatment with ACE inhibitors $[4,5]$. Numerous investigations into the potential role of $A C E$ as a susceptibility gene for diabetic nephropathy have been conducted over the past decade, with controversial results. Early meta-analyses attempted to reconcile these findings, but attempts to draw firm conclusions have been hindered by limited data, particularly when examining specific patient subgroups $[9,10]$.

Our present review of 47 studies reported since 1994 and comprising 14,727 subjects supports an overall association between the $A C E$ Ins/Del polymorphism and diabetic nephropathy. However, the possible heterogeneity of this association between the Asian and Caucasian subgroups could suggest that a simple summary pooled OR across all studies may not be valid. Particularly, type 2 diabetic Asians who are II homozygotes had a 35\% reduction in risk of diabetic nephropathy (defined on the minimal criterion of microalbuminuria) compared to those carrying the $\mathrm{D}$ allele. This positive finding is significantly different from that observed among Caucasians with type 2 diabetes (OR $0.90,95 \% \mathrm{CI}=0.78-1.04$ ). Interestingly, when cases were defined on the basis of advanced diabetic nephropathy, the reduction in risk associated with the II genotype became more comparable across the three major subgroups with ORs ranging from 0.68 to 0.76 ; this association reached statistical significance among Asians with type 2 diabetes, who represented the largest dataset for this subgroup analysis. This consistent magnitude of risk reduction across subgroups could suggest that the use of a minimal-case definition according to incipient diabetic nephropathy might have inadvertently introduced greater heterogeneity among Caucasian cases than a definition rooted in advanced nephropathy. The widespread use of a minimal criterion of microalbuminuria as seen in our meta-analysis may have stemmed from earlier landmark studies, which showed that in the majority of diabetic patients, microalbuminuria inexorably led to overt proteinuria [72]. More recently, however, it has been reported that such patients may not necessarily progress to proteinuria but may instead stay microalbuminuric, or even regress to normoalbuminuria [73]. Furthermore, regression from microto normoalbuminuria could occur in a substantial proportion of patients, but regression from proteinuria appears much less frequently [74]. Aside from case heterogeneity, the possibility of the Ins/Del polymorphism being associated more strongly with early renal changes among Asians than in Caucasians may also be considered. Interestingly, all three previous meta-analyses reported in 1998 did not place specific emphasis on the use of advanced diabetic nephropathy as a basis for defining cases $[9,11]$. This shortcoming may be attributed to the lack of the relevant studies at the time these reviews were performed $[9,10]$.

Several research groups have used control groups consisting solely of diabetic patients with normoalbuminuria despite a long duration of diabetes $[38,56]$. This approach could yield clearer evidence for a true association between $A C E$ Ins/Del and diabetic nephropathy, since the use of these controls can help reduce case misclassification. However, confining our analyses to studies with such 'long duration control groups' did not materially alter our findings. A possible explanation is that among studies that did not specify a requirement for a minimal diabetes duration, the control subjects may already have been diabetic for a significant period of time.

ACE inhibitors are already widely used in the clinical management of diabetic nephropathy. Several studies have examined how the effect of these drugs on diabetic nephropathy can be modulated by genetic variation at the $A C E$ locus. Among these studies, Caucasians with the II genotype were reported to respond more favourably to ACE inhibitors in terms of a reduction in diabetes-associated albuminuria than carriers of the D allele [4]. This differential response to ACE inhibitor treatment was also observed in the EURODIAB Controlled Trial of Lisinopril in IDDM [5]. Curiously, while the D allele has been linked with higher ACE activity [6], several studies have indicated that the DD genotype could be associated with better response to the anti-proteinuric effect of ACE inhibitors in patients with diabetic nephropathy [75] and other renal diseases [76]. With these counter-intuitive findings, the precise manner in which the $A C E$ genotype modifies response to ACE inhibitors remains unresolved. Clarification of this issue may conceivably be drawn from a more comprehensive haplotype analysis of the $A C E$ locus that extends beyond the mere consideration of the Ins/Del polymorphism [77].

Acknowledgements This study was supported by a research grant (NMRC/0850/2004) from the National Medical Research Council, Singapore. We would like to thank Dr Andrzej S. Krolewski for giving us his feedback on the manuscript.

\section{References}

1. National Institutes of Health, National Institute of Diabetes and Digestive and Kidney Diseases, Bethesda, MD. US (2003) Renal data system annual data report: atlas of end-stage renal disease in the United States

2. Singapore Renal Registry (1997) First report of the Singapore Renal Register

3. Lewis EJ, Hunsicker LG, Bain RP, Rohde RD (1993) The effect of angiotensin-converting-enzyme inhibition on diabetic nephropathy. The Collaborative Study Group. N Engl J Med 329: $1456-1462$

4. Jacobsen P, Rossing K, Rossing P et al (1998) Angiotensin converting enzyme gene polymorphism and ACE inhibition in diabetic nephropathy. Kidney Int 53:1002-1006 
5. Penno G, Chaturvedi N, Talmud PJ et al (1998) Effect of angiotensin-converting enzyme (ACE) gene polymorphism on progression of renal disease and the influence of ACE inhibition in IDDM patients: findings from the EUCLID Randomized Controlled Trial. EURODIAB Controlled Trial of Lisinopril in IDDM. Diabetes 47:1507-1511

6. Rigat B, Hubert C, Alhenc-Gelas F et al (1990) An insertion/ deletion polymorphism in the angiotensin I-converting enzyme gene accounting for half the variance of serum enzyme levels. J Clin Invest 86:1343-1346

7. Krolewski AS, Ng DPK, Canani LH, Warram JH (2001) Genetics of diabetic nephropathy: how far are we from finding susceptibility genes? Adv Nephrol Necker Hosp 31:295-315

8. Marre M, Bernadet P, Gallois Y et al (1994) Relationships between angiotensin I converting enzyme gene polymorphism, plasma levels, and diabetic retinal and renal complications. Diabetes 43:384-388

9. Tarnow L, Gluud C, Parving HH (1998) Diabetic nephropathy and the insertion/deletion polymorphism of the angiotensinconverting enzyme gene. Nephrol Dial Transplant 13:11251130

10. Kunz R, Bork JP, Fritsche L et al (1998) Association between the angiotensin-converting enzyme-insertion/deletion polymorphism and diabetic nephropathy: a methodologic appraisal and systematic review. J Am Soc Nephrol 9:1653-1663

11. Fujisawa T, Ikegami H, Kawaguchi Y et al (1998) Meta-analysis of association of insertion/deletion polymorphism of angiotensin I-converting enzyme gene with diabetic nephropathy and retinopathy. Diabetologia 41:47-53

12. Doria A, Warram JH, Krolewski AS (1994) Genetic predisposition to diabetic nephropathy. Evidence for a role of the angiotensin I-converting enzyme gene. Diabetes 43:690-695

13. Powrie JK, Watts GF, Ingham JN et al (1994) Role of glycaemic control in development of microalbuminuria in patients with insulin dependent diabetes. BMJ 309:1608-1612

14. Dudley CR, Keavney B, Stratton IM et al (1995) UK prospective diabetes study: XV. Relationship of renin-angiotensin system gene polymorphisms with microalbuminuria in NIDDM. Kidney Int 48:1907-1911

15. Fujisawa T, Ikegami H, Shen GQ et al (1995) Angiotensin Iconverting enzyme gene polymorphism is associated with myocardial infarction, but not with retinopathy or nephropathy, in NIDDM. Diabetes Care 18:983-985

16. Mizuiri S, Hemmi H, Inoue A et al (1995) Angiotensinconverting enzyme polymorphism and development of diabetic nephropathy in non-insulin-dependent diabetes mellitus. Nephron 70:455-459

17. Panagiotopoulos S, Smith TJ, Aldred GP et al (1995) Angiotensin-converting enzyme (ACE) gene polymorphism in type II diabetic patients with increased albumin excretion rate. J Diabetes Complicat 9:272-276

18. Schmidt S, Schone N, Ritz E (1995) Association of ACE gene polymorphism and diabetic nephropathy? The Diabetic Nephropathy Study Group. Kidney Int 47:1176-1181

19. Tarnow L, Cambien F, Rossing P et al (1995) Lack of relationship between an insertion/deletion polymorphism in the angiotensin I-converting enzyme gene and diabetic nephropathy and proliferative retinopathy in IDDM patients. Diabetes 44: 489-494

20. Rabensteiner D, Mayer G, Abrahamian H et al (1995) Relationship between angiotensin-I-converting enzyme polymorphism and microangiopathy in IDDM subjects. Diabetologia 38 (Suppl):A227

21. Chowdhury TA, Dronsfield MJ, Kumar S et al (1996) Examination of two genetic polymorphisms within the renin-angiotensin system: no evidence for an association with nephropathy in IDDM. Diabetologia 39:1108-1114

22. Doi Y, Yoshizumi H, Yoshinari M et al (1996) Association between a polymorphism in the angiotensin-converting enzyme gene and microvascular complications in Japanese patients with NIDDM. Diabetologia 39:97-102
23. Nakajima S, Baba T, Yajima Y (1996) Is ACE gene polymorphism a useful marker for diabetic albuminuria in Japanese NIDDM patients? Diabetes Care 19:1420-1422

24. Oh TG, Shin CS, Park KS et al (1996) Relationship between angiotensin I converting enzyme gene polymorphism and renal complications in Korean IDDM patients. Korean J Intern Med 11:133-137

25. Ohno T, Kawazu S, Tomono S (1996) Association analyses of the polymorphisms of angiotensin-converting enzyme and angiotensinogen genes with diabetic nephropathy in Japanese non-insulin-dependent diabetics. Metabolism 45:218-222

26. Yoshida H, Kuriyama S, Atsumi Y et al (1996) Angiotensin I converting enzyme gene polymorphism in non-insulin dependent diabetes mellitus. Kidney Int 50:657-664

27. Barnas U, Schmidt A, Illievich A et al (1997) Evaluation of risk factors for the development of nephropathy in patients with IDDM: insertion/deletion angiotensin converting enzyme gene polymorphism, hypertension and metabolic control. Diabetologia 40:327-331

28. Gutierrez C, Vendrell J, Pastor R et al (1997) Angiotensin Iconverting enzyme and angiotensinogen gene polymorphisms in non-insulin-dependent diabetes mellitus. Lack of relationship with diabetic nephropathy and retinopathy in a Caucasian Mediterranean population. Metabolism 46:976-980

29. Hibberd ML, Millward BA, Demaine AG (1997) The angiotensin I-converting enzyme (ACE) locus is strongly associated with age and duration of diabetes in patients with type I diabetes. J Diabetes Complicat 11:2-8

30. Jeffers BW, Estacio RO, Raynolds MV, Schrier RW (1997) Angiotensin-converting enzyme gene polymorphism in noninsulin dependent diabetes mellitus and its relationship with diabetic nephropathy. Kidney Int 52:473-477

31. Marre M, Jeunemaitre X, Gallois Y et al (1997) Contribution of genetic polymorphism in the renin-angiotensin system to the development of renal complications in insulin-dependent diabetes: Genetique de la Nephropathie Diabetique (GENEDIAB) study group. J Clin Invest 99:1585-1595

32. Pfohl M, Frost D, Koch M et al (1998) Lack of association between the insertion/deletion polymorphism of the angiotensin-converting-enzyme gene and diabetic nephropathy in IDDM patients. Horm Metab Res 30:276-280

33. Ringel J, Beige J, Kunz R, et al (1997) Genetic variants of the renin-angiotensin system, diabetic nephropathy and hypertension. Diabetologia 40:193-199

34. Demurov LM, Chistyakov DA, Chugunova LA et al (1997) Insertion/deletion of the angiotensin-converting enzyme gene in normalcy and among diabetics with vascular complications. Mol Biol 31:49-52

35. Schmidt S, Strojek K, Grzeszczak W et al (1997) Excess of DD homozygotes in haemodialysed patients with type II diabetes. The Diabetic Nephropathy Study Group. Nephrol Dial Transplant 12:427-429

36. Schmidt S, Ritz E (1997) Angiotensin I converting enzyme gene polymorphism and diabetic nephropathy in type II diabetes. Nephrol Dial Transplant 12(Suppl 2):37-41

37. Freire MB, van Dijk DJ, Erman A et al (1998) DNA polymorphisms in the ACE gene, serum ACE activity and the risk of nephropathy in insulin-dependent diabetes mellitus. Nephrol Dial Transplant 13:2553-2558

38. Grzeszczak W, Zychma MJ, Lacka B, Zukowska-Szczechowska E (1998) Angiotensin I-converting enzyme gene polymorphisms: relationship to nephropathy in patients with non-insulin dependent diabetes mellitus. J Am Soc Nephrol 9:1664-1669

39. Hanyu O, Hanawa H, Nakagawa O et al (1998) Polymorphism of the angiotensin I-converting enzyme gene in diabetic nephropathy in type II diabetic patients with proliferative retinopathy. Ren Fail 20:125-133

40. Huang XH, Rantalaiho V, Wirta O et al (1998) Angiotensinconverting enzyme insertion/deletion polymorphism and diabetic albuminuria in patients with NIDDM followed up for 9 years. Nephron 80:17-24 
41. Wu S, Xiang KS, Weng Q et al (1998) Relationship between angiotensin I converting enzyme gene polymorphism and diabetic nephropathy. Chin Med J 111:478-479

42. Young RP, Chan JC, Critchley JA et al (1998) Angiotensinogen T235 and ACE insertion/deletion polymorphisms associated with albuminuria in Chinese type 2 diabetic patients. Diabetes Care 21:431-437

43. Bouhanick B, Gallois Y, Hadjadj S et al (1999) Relationship between glomerular hyperfiltration and ACE insertion/deletion polymorphism in type 1 diabetic children and adolescents. Diabetes Care 22:618-622

44. De Cosmo S, Margaglione M, Tassi V et al (1999) ACE, PAI-1, decorin and Werner helicase genes are not associated with the development of renal disease in European patients with type 1 diabetes. Diabetes/Metab Res Rev 15:247-253

45. Kuramoto N, Iizuka T, Ito H et al (1999) Effect of ACE gene on diabetic nephropathy in NIDDM patients with insulin resistance. Am J Kidney Dis 33:276-281

46. Miura J, Uchigata Y, Yokoyama H et al (1999) Genetic polymorphism of renin-angiotensin system is not associated with diabetic vascular complications in Japanese subjects with longterm insulin dependent diabetes mellitus. Diabetes Res Clin Pract 45:41-49

47. Oue T, Namba M, Nakajima H et al (1999) Risk factors for the progression of microalbuminuria in Japanese type 2 diabetic patients - a 10 year follow-up study. Diabetes Res Clin Pract 46:47-55

48. Tomino Y, Makita Y, Shike T et al (1999) Relationship between polymorphism in the angiotensinogen, angiotensin-converting enzyme or angiotensin II receptor and renal progression in Japanese NIDDM patients. Nephron 82:139-144

49. Vleming LJ, van der Pijl JW, Lemkes HH et al (1999) The DD genotype of the ACE gene polymorphism is associated with progression of diabetic nephropathy to end stage renal failure in IDDM. Clin Nephrol 51:133-140

50. Wong TY, Chan JC, Poon E, Li PK (1999) Lack of association of angiotensin-converting enzyme (DD/II) and angiotensinogen M235T gene polymorphism with renal function among Chinese patients with type II diabetes. Am J Kidney Dis 33:1064-1070

51. Hsieh MC, Lin SR, Hsieh TJ et al (2000) Increased frequency of angiotensin-converting enzyme DD genotype in patients with type 2 diabetes in Taiwan. Nephrol Dial Transplant 15:10081013

52. Van Ittersum FJ, de Man AM, Thijssen S et al (2000) Genetic polymorphisms of the renin-angiotensin system and complications of insulin-dependent diabetes mellitus. Nephrol Dial Transplant 15:1000-1007

53. Tarnow L, Kjeld T, Knudsen E et al (2000) Lack of synergism between long-term poor glycaemic control and three gene polymorphisms of the renin angiotensin system on risk of developing diabetic nephropathy in type I diabetic patients. Diabetologia 43:794-799

54. Araz M, Yilmaz N, Gungor K et al (2001) Angiotensin-converting enzyme gene polymorphism and microvascular complications in Turkish type 2 diabetic patients. Diabetes Res Clin Pract 54:95-104

55. Azar ST, Zalloua PA, Medlej R, Halabi G (2001) The DD genotype of the ACE gene polymorphism is associated with diabetic nephropathy in the type-1 diabetics. Endocr Res 27:99-108

56. Gohda T, Makita Y, Shike T et al (2001) Association of the DD genotype and development of Japanese type 2 diabetic nephropathy. Clin Nephrol 56:475-480

57. Hadjadj S, Belloum R, Bouhanick B et al (2001) Prognostic value of angiotensin-I converting enzyme I/D polymorphism for nephropathy in type 1 diabetes mellitus: a prospective study. $\mathrm{J}$ Am Soc Nephrol 12:541-549

58. Taniwaki H, Ishimura E, Matsumoto N et al (2001) Relations between ACE gene and ecNOS gene polymorphisms and resistive index in type 2 diabetic patients with nephropathy. Diabetes Care 24:1653-1660
59. Viswanathan V, Zhu Y, Bala K et al (2001) Association between ACE gene polymorphism and diabetic nephropathy in South Indian patients. J Pancreas 2:83-87

60. Araz M, Okan V, Celen Z, Aynacioglu S (2002) Angiotensin converting enzyme gene polymorphism and glomerular filtration rate changes in type 2 diabetic patients. Int J Clin Pract 56:416-418

61. Fradin S, Goulet-Salmon B, Chantepie M et al (2002) Relationship between polymorphisms in the renin-angiotensin system and nephropathy in type 2 diabetic patients. Diabetes Metab 28:27-32

62. De Azevedo MJ, Dalmaz CA, Caramori ML et al (2002) ACE and PC-1 gene polymorphisms in normoalbuminuric Type 1 diabetic patients: a 10-year prospective study. J Diabetes Complicat 16:255-262

63. Lee YJ, Tsai JC (2002) ACE gene insertion/deletion polymorphism associated with 1998 World Health Organization definition of metabolic syndrome in Chinese type 2 diabetic patients. Diabetes Care 25:1002-1008

64. Ha SK, Park HC, Park HS et al (2003) ACE gene polymorphism and progression of diabetic nephropathy in Korean type 2 diabetic patients: effect of ACE gene DD on the progression of diabetic nephropathy. Am J Kidney Dis 41:943-949

65. Hadjadj S, Gallois Y, Alhenc-Gelas F et al (2003) AngiotensinI-converting enzyme insertion/deletion polymorphism and high urinary albumin concentration in French Type 2 diabetes patients. Diabet Med 20:677-682

66. Okuno S, Utsugi T, Ohno T et al (2003) Angiotensin-converting enzyme gene polymorphism as a potent risk factor for developing microalbuminuria in Japanese patients with type 2 diabetes mellitus: a 9-year follow-up study. J Int Med Res 31: 290-298

67. Ha SK, Seo JK (1997) Insertion/deletion polymorphism in ACE gene as a predictor for progression of diabetic nephropathy. Kidney Int 52 (Suppl 60):S28-S32

68. Whitehead A (2002) Meta-analysis of controlled clinical trials. Wiley, Chichester, pp 197-213

69. Fleiss JL (1993) The statistical basis of meta-analysis. Stat Methods Med Res 2:121-145

70. Armitage P, Berry G (1994) Statistical methods in medical research, 3rd edn. Blackwell, London, p 521

71. Araki S, Ng DP, Krolewski B et al (2003) Identification of a common risk haplotype for diabetic nephropathy at the protein kinase C-beta1 (PRKCB1) gene locus. J Am Soc Nephrol 14: 2015-2024

72. Mogensen CE, Christensen CK (1984) Predicting diabetic nephropathy in insulin-dependent patients. N Engl J Med 311: 8993

73. Perkins BA, Ficociello LH, Silva KH et al (2003) Regression of microalbuminuria in type 1 diabetes. N Engl J Med 348:22852293

74. Ellis D, Lloyd C, Becker DJ et al (1996) The changing course of diabetic nephropathy: low density lipoprotein cholesterol and blood pressure correlate with regression of proteinuria. Am J Kid Dis 27:809-818

75. Ha SK, Lee SY, Park HS et al (2000) ACE DD genotype is more susceptible than ACE II and ID genotypes to the antiproteinuric effect of ACE inhibitors in patients with proteinuric non-insulindependent diabetes mellitus. Nephrol Dial Transplant 15:16171623

76. Perna A, Ruggenenti P, Testa A et al (2000) ACE genotype and ACE inhibitors induced renoprotection in chronic proteinuric nephropathies. Kidney Int 57:274-281

77. Keavney B, McKenzie CA, Connell JMC et al (1998) Measured haplotype analysis of the angiotensin-I converting enzyme gene. Hum Mol Genet 7:1745-1751 